\title{
Women Empowerment and Societal Development in North-east Nigeria
}

Odigwe Francisca Nonyelum, Okoi Ikpi Inyang

Department of Educational Administration and Planning, University of Calbar, Nigeria

Published Date: November 2017

Published Online: $25^{\text {th }}$ November 2017

Corresponding Author: Odigwe Francisca, Department of Eductional Administration and Planning, University of Calbar, Nigeria, francadigwe@yahoo.com

\section{Introduction}

The perennial socio-political problems in the NorthEast region of Nigeria have crippled the development of that area of the country. The major problems emanate from mass poverty, Illiteracy, widespread disease of public health importance and above all, insecurity of lives and property arising from the boko haram insurgency. In all the major indicators of human development, the North-East of Nigeria is the least performing geo-political zone. Most of the poverty- stricken states are concentrated in that region.

\section{Background and Perspectives}

With the Federal Government commitment to develop the North East Region of the Country, the most effective way to achieve this laudable goal is to target specific project that will have "a multiplier effect" in the economy of the region. It is important to note that one critical challenge of our time is the realization that poverty has more adverse effects on women in the society than on men. It is also regrettable to note that prevailing conditions locally and globally aggravate the vulnerability of women and consequently lead to a continuous increase in the number of females within the poverty bracket. The condition include lack of education, discriminatory socio-economic and political practices, job discrimination, and many others (Nwaogu 2004). The crucial role of women as social motivators, economic enablers and key agents of change in a wide range of interest areas such as education, health, agriculture, small and medium scale entrepreneurship cannot be over emphasized. The natural endowment of women makes their contributions to successful implementation of any human endeavour unique and indispensable. (Egonawan 2007)

The importance of the role that women can and should play and have indeed been playing in promoting the well being of society has never on doubt. This is because women comprise more than one half of the world's human resources. Therefore, the economic and social empowerment of women must be embarked upon with uncompromising determination if we are to address the issue of mass poverty with any measure of success in the north east region of Nigeria.

Skill acquisition is the key to fight for the elimination of hunger and poverty, reduction or elimination of joblessness in the society and reduction of crime through effective engagement of youths. Women empowerment through skill acquisition has been described by many as the recipe for eradicating extreme poverty and hunger, thereby creating avenue for jobs and wealth creation. The right of women to be self-reliant and self employed can be achieved through the acquisition of skills that are related to their environment. This will enable them engage in small scale enterprises, which is one of the ways of reducing the incidence of poverty and unemployment among women in the society.

UNICEF information sheet, (2007) states that 
educating women helps develop self confidence, protection from sexual exploitation, improved health care, better child education and poverty eradication for generations to come. Women empowerment is a global topic. The United Nations (UN) included gender and women empowerment in its development agenda as it is an important tool for achieving the millennium development goals.

Vocational skills acquisition programmes through the distance learning mode is a sure means for women to gain basic education and I or vocational skills. According to Okorie and Ezeji (1988) the acquisition of the requisite skills is a means of increasing the productive power of any nation.

Moreso entrepreneurship is now recognized worldwide as a basic means of promoting and improving innovative activities and capabilities. Entrepreneurship according to Kayode (2006) is the willingness and ability of an individual to seek out investment and be able to establish and run an enterprise successfully based on identifiable opportunities. Entrepreneurship training is aimed at making men and women self-reliant and selfsufficient, and able to provide for others. This can lead to economic readjustment and redistribution of wealth and related social status. Training and retraining is very essential and necessary for the growth and development of the North-East. Training and retraining of women gives room for adaptability, flexibility, job improvement, acquisition of new skills and a better orientation to work. Therefore training and retraining of women will always be beneficial to the individuals, society and the nation in order for it to be productive, self reliant and eqalitarian, (Obi, Ric and Zakar, 2005).

The role of entrepreneurship in the economic, political and social development of the region involves more than increasing per capita out-put and income, it involves initiating and constituting change in the structure of business and society, which is accompanied by growth and increased output, leading to sustainable development of self, the immediate society and the nation at large.

UNESCO (2002) stated that women form a high percentage of the population, and as such they need quality literacy education to be able to contribute their quota to the development of the nation. There is now the realization that sustainable human development cannot be effective if half of the human race (the women-folk) remain ignorant, marginalized and discriminated against. The provision of quality literacy education to them will greatly improve lives and livelihood and will no doubt have a great and sustainable social and economic impact on the women folk, and the nation in general. This was based on the belief that the full integration of women in all aspects of political, economic and social life is essential if the obstacles to the achievement of the goals and objectives for women are to be overcome (Okorjie, 2011).

The importance of literacy and women empowerment in promoting gender equality and the advancement of women was further stressed by the millennium development goals (2000). Olomukoro (2012) opined that the national policy on women was approved and adopted in Nigeria in the year 2000 , of which the goal of the policy was full integration of women into the social and political status as a means of developing the nation's human resources.

According to Olomukoro (2012) literacy is not just the ability to read and write, but also the ability to use printed and written information to function in society, to achieve one's goal and to develop one's knowledge and potentials. Imhabekhai and Olomukoro (2007) pointed out that literacy is a basic instrument in social transformation and modernization. It influences the rate of development and its possession or otherwise facilitates or retards the level of development.

In general, education wipes away ignorance, political apathy and encourages mutual understanding and cooperation among the various strata of society. The empowerment potential of women education can translate into political participation and thus contribute to the quality of public policies and to democracy.

\section{Statement of Problem}

The North East in Nigeria has been witnessing drastic and frantic security challenges for some years now 
and the insecurity situation has been partly attributed to unemployment in the region. Though, the crises surfaced in the forms of commercial, religious, political, social and economic unrests resulting in the loss of lives and property. But Judging from the happenings, it is seen by many as sectarian violence arising from rampant economic inequalities.

Bearing the foregoing considerations in mind, this study attempts to address the topical issue of the economic empowerment of women in the development of the society. The question now is: What has the government done, should do or is doing to effectively integrate women's development and empowerment to ensure their free participation in the economic development process in the North East? Moreso, to what degree does education influence the effective participation of women in the development process of the society? It is in the light of the above questions, that this research seeks to address the gender inequality of educational opportunities in the North-East region of Nigeria.

\section{Purpose of the Study}

This study aimed at determining the relationship between women empowerment and societal development in the North-East region of Nigeria. Specifically, the study aimed at determining whether:

(1) Women empowerment through skill acquisition relate to societal development

(2) Women empowerment through entrepreneurship training relate to societal development

(3) Women empowerment through quality literate education relate to societal development.

\section{Research Questions}

The following questions were stated to guide the study.

(1) To what extent does women empowermen

\section{Result Presentation}

\section{Research Question One}

through vocational skill acquisition relate to societal development in terms of:

i. Fashion designing

ii. Cake baking

iii. Decoration and

iv. Soap making

(2) How does women empowerment through entrepreneurship training in terms of:

i. Information and communication technology (ICT)

ii. Barbing \& Hair dressing salons

iii. Electrical work - Basic domestic and auto electrical work

iv. Beads making and braiding

v. Carpentry

(3) To what extent does women empowerment through quality literate education in terms of reading, writing,

arithmetic relate to societal development?

\section{Methodology}

This study adopted a correlation design. A correlation study determines whether or not two variables are correlated, meaning an increase in one variable corresponds to an increase or decrease in the other. The population of this studies was 15,865 women within the age's of (30-40). A multi-stage sampling technique was adopted. A sample size of six hundred women was selected based on the sampling procedures on age bracket (30-40). The items of the questionnaire was validated by experts in measurement \& evaluation.

A four-point scale questionnaire that ranged from 4 for Strongly Agree, (SA), 3 for Agree (A); 2 for Disagree, (D), and Strongly Disagree (SD) 1was used. With the above 2.5 regarded as significantly agree assessment for the discipline based on the component of the variables used in the study. The Pearson Product Moment Correlation Coefficient $(r)$ was used to test reliability that yielded correlation coefficient of 0.82

To what extent does women empowerment through vocational skill acquisition relate to social development? 
Table 1

\begin{tabular}{ccccc}
\hline $\mathrm{S} / \mathrm{N}$ & Component & Means & SD & Remark \\
\hline 1 & Fashion designing & 3.59 & 0.95 & Agree \\
2 & Cake baking & 3.53 & 0.92 & Agree \\
3 & Decoration & 3.36 & 0.91 & Agree \\
4 & Soap making & 3.26 & 0.9 & Agree \\
\hline
\end{tabular}

The table above shows that all items on women empowerment through vocational skills acquisition (fashion designing, cake baking decoration and soap making) were perceived and rated agrees. Invariably all items showed strongly agree means ranging between 3.26 and 3.59.

\section{Research question 2}

To what extent does women empowerment through entrepreneurship training relate to social development?

Table 2 Mean and standard deviation of women empowerment through entrepreneurship training

\begin{tabular}{|c|c|c|c|c|}
\hline $\mathrm{S} / \mathrm{N}$ & Component & Means & SD & Remark \\
\hline 1 & Information and Communication Technology (ICT) & 3.36 & 0.91 & Agree \\
\hline 2 & Barbing and hair Dressing Saloons & 3.26 & 0.9 & Agree \\
\hline 3 & $\begin{array}{l}\text { Electrical Work (Basic) Domestic and Auto Electrical } \\
\qquad \text { Work }\end{array}$ & 1.22 & 0.38 & Disagree \\
\hline 4 & Beads Making and Branding & 3.31 & 0.91 & Agree \\
\hline 5 & Capentry & 3.18 & 0.88 & Agree \\
\hline
\end{tabular}

The result of table 2 showed that respondents positively rated ICT, barbing and hair dressing salons, beads making and braiding as empowerment through entrepreneurship training. However they perceived electrical work negatively.

\section{Research question three}

To what extent does women empowerment through quality literate education in terms of reading, writing arithmetic relate to societal development.

Table 3 Mean and standard deviation of empowerment through quality literate education and social development

\begin{tabular}{ccccc}
\hline $\mathrm{S} / \mathrm{N}$ & Component & Means & SD & Remark \\
\hline 1 & Reading & 3.11 & 0.86 & Agree \\
2 & Writing & 2.42 & 0.91 & Disagree \\
3 & Arithmetic & 1.5 & 0.83 & Disagree \\
\hline
\end{tabular}

The result from this table shows that of the three

component of quality literate education only reading were rated positive while writing and arithmetic 
were rated negative. That means respondents has no empowerment on quality education interms of writing and arithmetic.

\section{Discussion}

The result of research question one showed that there is a positive relationship between women empowerment through acquisition of vocational skills in terms of fashion designing, cake baking decoration and soap making with societal development, this means that respondents strongly agreed to the fact that empowerment through vocational skill acquisition improved societal development. The result of this finding is in line with the findings of Ezegbe and Akubue (2012) who posited that skill acquisition is key in the fight to eliminate hunger and poverty, reduction or elimination of joblessness in the society and reduction of crime through effective engagement of youths. They added that the rights of women to be self reliant and self employed can be achieved through the acquisition of skills that are related to the environment. Women empowerment through vocational skill acquisition are the bridge to a prosperous future for women in North-Eastern Nigeria, Therefore the empowerment must be given the priority it deserves. This will enable them engage in small scale enterprises, which is one of the ways of reducing poverty and unemployment among women in the society. Therefore, women empowerment through skills acquisition has been described by many as the recipe for eradicating extreme poverty and hunger, thereby opening up avenues for job and wealth creation.

The result of research question two also showed a positive relationship between women empowerment through information and communication technology (ICT), barbing and hair dressing saloons, electrical work, beads making, braiding, carpentry and societal development. The result is in line with the findings of Kayode (2006), who posited that entrepreneurship is the willingness and ability of an individual to seek out investment and be able to establish and run an enterprise successfully based on identifiable opportunities.
Basically, entrepreneurship training aimed at making women who can be self-reliant and self sufficient, and who will be able to provide for others. This can lead to economic re-adjustement and re-distribution of wealth and related social status. The economic and social empowerment of women must be embarked upon with uncompromising determination if we are to address the issue of mass poverty. The crucial role of women as social and economic enablers and key agents of change in a wide range of interest areas such as; education, health, agriculture, small and medium entrepreneurship cannot be overemphasized. It is on this note that Kayode (2006) further observed that empowerment in vocational and technical skills, entrepreneurship is a roadmap for the future of the youths, adding that out of school youths are on the journey to wealth and hope. The result of research question three revealed that empowerment women through quality literate education is negative. That is respondents perceive quality literate education in terms of reading, writing, arithmetic to social development very low. This is because formal education was not given it required status in the North-East of Nigeria. Education is a veritable weapon against ignorance, poverty, disease, superstition and backwardness. This could be the reason lgwe (2007) described education as an invaluable instrument for political, social, economic, scientific and technological development.

The findings of this study is also in line with that of UNESCO ${ }^{[3]}$ where it was stated that women from a high percentage of the population and as such, they need quality literacy education to be able to contribute their quota to the development of society. The provision of quality literate education to women will greatly improve lives and livelihood and will no doubt have a great and sustainable social and economic impact on the society. Education is indeed the network of all human efforts undertaken informal, formal, traditional and modern ways to make individuals cultivate the right set of habits and skills which will enable them to survive and to operate meaningful as rational members of the society.

\section{Recommendations}


1. Government and non-governmental organization should ensure comprehensive training of women to acquire skills that will enable them contribute maximally to the development of the society.

2. Early awareness of the programme in acquiring entrepreneurship skills and attitude will accelerate the development of those skills and attitudes. Governments should create awareness among the populace and the need for educational training as this expose them to the various skills and knowledge for their survival in the society.

3. The Federal, State and Local Government should create enabling laws for functional education in north-east which will encourage education for training, self-reliance, and entrepreneurship.

\section{References}

[1] Olo'mukoro, C. O. (2012). Confluence of Literacy Education Programme on Socio-Economic \& Psychological Empowerment of Women in Edo and Delta States, Nigeria Unpublished Ph.D thesis, University of Ibadan.

[2] Okofie C.E.E. (2011) Achieving Gender Equality and women's empowerment in Nigeria: Should women want in hope or expectation. Inaugural lecture series, University of Benin, Benin city, Nigeria. [3] UNESCO (2002) Education for all: An international Strategy to operationalized the Dakor Framework for Action of Education for all http://www.org/educationefe/global.co.comprehens ive.efa-strategy-2002-gliful

[4] Imhabekhai, E and Olonukoro C. 0. (2007) Integrating the nomads into wafinal Development programme Through Adult Education. In a Uwawoke E. A. Okediran(eds) International Journal of Forum for African Women Educationists Nigeria 42-48

[5] Nwaogu I. O. (2004) Fundamentals of Entrepreneurship in Education Management, Enugu Cheston Agency Ltd.

[6] UNICEF Information sheet (2009) Nigeria country office

[7] Kayode 0. F. (2006) Entrepreneurship Theory Strategy and Practice. Bee printing and pub.co. [8] Ezegbe, B. N \& Akubue, F (2012), An Appraisal of the status of Nigerian women: Educational Implication and National Development. American Journal of Sociological Research, 2(2) 27-31.

[9] Okemakinde, T (2014), Women Education: Implications for National Development in Nigeria. European Journal of Globalization and Development Research 9(1) 553-565. 